\title{
Pengembangan Media Flash Card untuk Meningkatkan Hasil Belajar Bahasa Indonesia Siswa SDN Donggo
}

\author{
Desy Ningsih Komalasari ${ }^{1}$, Zulkifli ${ }^{2}$ \\ 1,2 STKIP Taman Siswa Bima, Nusa Tenggara Barat, Indonesia \\ E-mail: desyningsih113@gmail.com
}

\begin{tabular}{l}
\hline Article Info \\
\hline Article History \\
Received: 2021-08-20 \\
Revised: 2021-09-10 \\
Published: 2021-10-15 \\
\\
Keywords: \\
Flash Card; \\
Learning Outcomes; \\
Indonesian Language.
\end{tabular}

\begin{abstract}
This research is a development research by producing a flashcard media product that aims to improve the learning outcomes of Indonesian students at Donggo Dori Dungga Elementary School where before presenting the questions only use image media so that students are less attractive and motivated in learning so that it affects student learning outcomes. So that student learning outcomes are below the standard and categorized as low. This research on the development of flashcard media or Research and Development (R\&D) was adapted from the ADDIE development model (Analysis, Design, Development, Implementation, and Evaluation). The resulting flashcard media product is in the form of a package called media flash card with an environmental theme, The results of research and development of flash card media after being given questions, the researchers distributed response questionnaires to students to find out student responses in using flash card media. Based on a small-scale trial consisting of 10 Donggo Dori Dungga Elementary School students showed a positive response to the presentation learning media, the highest on one of the flash card media design statements used attracted a percentage of $92 \%$ strongly agree. While the researchers conducted a large scale to determine the effectiveness of the flash card media, the researchers carried out this stage with a total of 20 students of SDN Donggo Dori Dungga. Student responses to the flash card media used "strongly agree" the highest percentage is $97.5 \%$.
\end{abstract}

\begin{tabular}{l}
\hline Artikel Info \\
\hline Sejarah Artikel \\
Diterima: 2021-08-20 \\
Direvisi: 2021-09-10 \\
Dipublikasi: 2021-10-15
\end{tabular}

Kata kunci:

Kartu Flash;

Hasil Belajar;

Bahasa Indonesia.

\begin{abstract}
Abstrak
Penelitian ini adalah penelitian pengembangan dengan menghasilkan sebuah produk media flashcard yang bertujuan untuk meningkatkan hasil belajar bahasa Indonesia siswa sdn donggo dori dungga dimana sebelum melakukan penyajian soal hanya menggunakan media gambar sehingga siswa kurang menarik dan bermotivasi dalam pembelajara sehingga mempengaruh pada hasil pembelajaran siswa. Sehingga hasil belajar siswa dibawah standard dan dikatagorikan rendah. Penelitian pengembangan media flashcard atau Research and Development (R\&D) ini diadaptasi dari model pengembangan ADDIE (Analysis, Design, Development, Implementation, dan Evaluation). Produk media flashcard yang dihasilkan berupa satu paket yang bernama media flash card yang bertemakan lingkungan, Hasil penelitian dan pengembangan media flash card setelah diberikan soal pertanyaan peneliti membagikan angket respon pada siswa untuk mengetahui tanggapan siswa dalam penggunaan media flash card. Berdasarkan uji coba skala kecil terdiri dari 10 siswa SDN donggo dori dungga menunjukkan tanggapan yang positif terhadap media pembelajaran presentasi paling tinggi pada salah satu pernyataan desain media flash card yang digunakan menarik persentase $92 \%$ sangat setuju. Sedangkan peneliti melakukan skala besar untuk mengetahui keefektifan media flash card peneliti melakukan tahap ini dengan jumlah 20 siswa SDN donggo dori dungga. Respon siswa pada media flash card yang digunakan "sangat setuju" persentase paling tinggi yaitu 97,5\%.
\end{abstract}

\section{PENDAHULUAN}

Media dalam proses pembelajaran merupakan perantara atau pengantar sumber pesan dengan penerima pesan, merangsang pikiran, perasaan, perhatian dan kemauan sehingga terdorong serta terlibat dalam pembelajaran. Proses pembelajaran pada dasarnya juga merupakan proses komunikasi, sehingga media yang digunakan dalam pembelajaran disebut media pembelajaran. Media pembelajaran biasanya digunakan guru sebagai alat untuk mempertinggi proses interaksi antara guru dengan siswa dalam proses pembelajaran. Proses pembelajaran akan berjalan efektif dan efisien apabila guru memiliki kreativitas tinggi dalam menciptakan dan memanfaatkan media pembelajaran dengan baik. 
Penggunaan media pembelajaran sangat penting dalam proses pembelajaran, media pembelajaran yang digunakan harus kreatif, inovatif dan mampu mengubah suasana kelas menjadi lebih menyenangkan dan lebih menarik. Kegiatan belajar mengajar yang diikuti dengan pemakaian media pembelajaran sangat besar artinya bagi keberhasilan belajar siswa, karena akan membantu siswa memahami apa yang diajarkan. Penggunaan media pembelajaran dapat membantu siswa dalam melihat, merabah, mengungkapkan dengan pemikirannya secara langsung objek yang sedang mereka pelajari, sehingga konsep abstrak yang mereka pelajari akan mengendap, melekat, dan tahan lama jika mereka melihat objek yang konkret. Kurangnya inovasi dan kreativitas guru dalam menggunakan media pembelajaran sehingga kegiatan pembelajaran bahasa Indonesia berlangsung monoton dan membosankan salah satu media flaschcard pembelajaran yang digunakan oleh guru untuk mewujudkan situasi pembelajaran yang kondusif, aktif, kreatif, efektif, dan menyenangkan dalam pembelajaran Bahasa Indonesia. Adapun tujuan yang utama dalam penelitian ini. Mengingat rendahnya hasil belajar siswa khusunya mata pelajaran Bahasa indonesia makan peneliti tertarik untuk mengangkat dengan berbagai langkah penelitian.

a. Media flashcard

Media flashcard adalah salah satu media yang berbentuk gambar yang berukuran $25 \mathrm{x}$ $30 \mathrm{~cm}$. gambargambar yang dibuat dalam media flashcard dapat menggunakan tangan, berupa foto atau memanfaatkan gambar atau foto yang sudah ada dan ditempelkan pada lembaran-lembaran flashcard.gambar yang terdiri pada flashcard merupakan rangkaian pesan atau arti dari gambar tersebut yang dicantumkan pada bagian belakang kartu (Susilana, dan Riyana, 2009: 94).

Media Flashcard berkarakter khusus yang dibesarkan. Baik teks maupun gambarnya sehingga media ini mampu membuat anakanak tertarik dalam proses pembelajaran pada media Flashcard ini guru dapat memilih isi cerita atau topik yang sesuai dengan tema yang diinginkan dan masih tergolong dalam ruang lingkup pembelaran yang sama. Menurut [2] media Flashcard adalah media pembelajaran dalam bentuk kartun bergambar. Gambar yang ada pada media merupakan rangkainya pesan yang disajikan dengan keterangan. Sedangkan [3], menjelaskan, bahwa media Flashcard adalah kartun yang berisi gambar atau tulisan berhubungan dengan konsep. Definisi lain di ungkapkan oleh [4] bahwa media Flashcard kartu yang digunakan untuk mengkaji ulang dalam proses belajar jadi media Flashcard merupakan media yang membantu dalam mengingat dan mengkaji ualng bahan pembelajaran seperti definisi atau istila, simbol- simbol ejaan bahasa asing, rumusanrumusan dan lain-lain.

Media Flashcard berisi cerita singkat tenang topik yang sesuai dengan isi pada gambar atau tema yang terdapat pada media Flashcard yang berukuran besar. Untuk menarik perhatian atau membangkitkan semangat siswa dalam proses pembelajaran dengan adanya minat berkomunikasi akan meningkatkan pula hasil pembelajaran siswa. Maka siswa tersebut akan lebih mudah memahami materi yang dapat dalam pembelajaran. Media Flashcard dengan memiliki kelebihan dalam pembelajaran oleh [2] diantaranya sebagai berikut: 1) mudah dibawa kemana-mana karena beratnya ringan, 2) praktis dalam pembuatan dan menggunakanya, sehingga siswa bisa belajar dengan baik menggunakan media ini, 3) mengikutsertakan siswa untuk mengikuti pembelajaran secara aktif, 4) media Flashcard juga gampang di ingat kartun ini bergambar dan sangat menarik perhatian, memuat huruf atau angka yang simple, sehingga merangsang otak untuk lebih lama mengingat pesan yang ada. Media ini sangat menyenangkan unruk digunakan sebagi media pembelajaran, bahkan dapat digunakan dalam bentuk bermain.

\section{b. Hasil Belajar}

Setiap orang yang melakukan kegiatan belajar ingin mengetahui hasil belajar yang telah dicapainya, karena hasil belajar merupakan tolak ukur bagi keberhasilan seseorang yang telah melakukan kegiatan belajar. Hamalik (2013:30), menyatakan bahwa hasil belajar adalah perubahan tingkah laku pada seseorang, misalnya dari tidak tau menjadi tau, dan dari tidak mengerti menjadi mengerti. Sejalan dengan pendapat Dimyati dan Mudjiono (2013:3), menyatakan bahwa hasil belajar merupakan hasil dari suatu interaksi tindak belajar dan tindak mengajar. Dari sisi guru, tindak mengajar diakhiri dengan proses evaluasi hasil belajar. Dari sisi siswa, hasil belajar merupakan berakhirnya 
pengajaran dari puncak proses belajar. Hasil belajar siswa pada hakikatnya adalah perubahan mencakup bidang kognitif, afektif dan psikomotarik berorentasi pada proses belajar mengajar yang dialami (Sudjana, Nana, 2013). Hasil belajar menggambarkan keterampilan, pengetahuan, kemampuan atau nilai yang diukur harus dikumpulkan siswa setelah menyelesaikan program atau kegiatan pembelajaran (USC dalam Paolini, 2015: 24). Hal senada juga dikemukakan Rusman (2012:123), hasil belajar adalah sejumlah pengalaman yang diperoleh siswa mencakup aspek kognitif, afektif, dan psikomotor.

Dari beberapa pendapat tersebut, dapat disimpulkan bahwa hasil belajar merupakan perubahan tingkah laku yang mencakup kemampuan kognitif, afektif, dan psikomotor yang diperoleh siswa setelah mengalami aktivitas belajar, Terdapat beberapa indikator yang digunakan dalam mengukur hasil belajar siswa, berikut disajikan data awal hasil belajar siswa yang dijadikan sebagai sampel penelitian sebagai berikut:

Tabel 1. hasil Belajar siswa

\begin{tabular}{cccccc}
\hline \multirow{2}{*}{ No } & \multirow{2}{*}{ Inisial } & \multicolumn{2}{c}{ Nilai Tahap I } & \multicolumn{2}{c}{ Nilai Tahap II } \\
\cline { 3 - 6 } & & $\mathbf{S}$ & $\mathbf{N}$ & $\mathbf{S}$ & $\mathbf{N}$ \\
\hline 1 & AM & 6 & 60 & 9 & $60 \%$ \\
\hline 2 & MH & 11 & 73 & 11 & $73 \%$ \\
\hline 3 & SL & 6 & 60 & 8 & $53 \%$ \\
\hline 4 & SM & 14 & 93 & 9 & $60 \%$ \\
\hline 5 & FR & 5 & 33 & 6 & $60 \%$ \\
\hline 6 & NR & 9 & 60 & 11 & $73 \%$ \\
\hline 7 & HD & 11 & 73 & 11 & $73 \%$ \\
\hline 8 & NP & 6 & 73 & 9 & $60 \%$ \\
\hline 9 & FA & 9 & 60 & 11 & $73 \%$ \\
\hline 10 & NS & 9 & 60 & 1 & $73 \%$ \\
\hline
\end{tabular}

Pendapat yang paling terkemuka adalah yang disampaikan oleh Bloom yang membagi klasifikasi hasil belajar dalam 3 ranah, yaitu kognitif, afektif, dan psikomotorik (Byram \& $\mathrm{Hu}$, 2013: 57). Ranah kognitif, berkaitan dengan hasil belajar intelektual yang terdiri atas 6 aspek yaitu pengetahuan, pemahaman, penerapan, analisis, sintesis, dan penilaian. Ranah afektif, berkaitan dengan sikap dan nilai. Ranah afektif meliputi lima jenjang kemampuan yaitu menerima, menjawab, atau reaksi, menilai, organisasi dan karakterisasi dengan suatu nilai atau kompleks nilai. Ranah psikomotor meliputi keterampilan motorik, manipulasi benda-benda, koordinasi neuromascular (menghubungkan, mengamati). Jika dikaitkan dengan penelitian ini, peneliti hanya akan mengambil hasil pembelajaran kognitif saja.

\section{METODE PENELITIAN}

Metode yang digunakan dalam penelitian ini adalah penelitian dan pengembangan menggunakan model Borg dan Gall. Pengemba-ngan adalah suatu proses yang dipakai untuk mengembangkan dan memvalidasi produk pengembangan. Model penelitian pengembangan (Research and Development/ R\&D) merupakan metoda penelitian yang digunakan untuk meneliti sehingga menghasilkan produk baru, dan selanjutnya menguji keefektivan produk tersebut. Langkah-langkah dalam penelitian ini terdiri atas sepuluh tahapan yaitu (1) Potensi dan masalah, (2) pengumpulan data, (3) Desain Produk, (4) Validasi desain, (5) Revisi produk, (6) Ujicoba Produk, (8) Ujicoba pemakain, (9) Rivisi Produk, (10) Produk masal (Sugiyono, 2010: 407). Instrumen yang digunakan untuk mengumpulkan data yaitu tes dan kuisioner. Subjek pada penelitian ini adalah siswa SDN Dori Dungga Kecamatan Donggo Kabupaten Bima. Uji kelayakan produk dilakukan oleh ahli materi, ahli media, dan peserta didik dan teknik analisis data dilakukan secara kuantitatif dan kualitatif.

\section{HASIL DAN PEMBAHASAN}

\section{A. Ujicoba Penggunaan}

a) Ujicoba Skala Kecil

Berdasarkan hasil penelitian dan pengemba-ngan, pada tahap ujian coba kelomok kecil yakni dilakukan pada siswa yang berjumlah 10 orang siswa. uji coba pertama telah dilakukan pada tanggal 5 Oktober 2020. Adapun hasil belajar siswa pada kelompok kecil dilihat pada tabel dibawah ini:

Tabel 2. Hasil Belajar Mahasiswa Skala kecil pada Tahap I dan II

\begin{tabular}{clccc}
\hline No & Aspek & $\begin{array}{l}\text { Skor } \\
\text { Max }\end{array}$ & JML & \% \\
\hline 1 & $\begin{array}{l}\text { Desain media flash } \\
\text { card yang digunakan } \\
\text { menarik }\end{array}$ & 40 & 37 & $92 \%$ \\
\hline 2 & $\begin{array}{l}\text { Gambar di dalam } \\
\text { media flash card } \\
\text { sangat indah }\end{array}$ & 40 & 37 & $92,5 \%$ \\
\hline 3 & $\begin{array}{l}\text { Ukuran dan tulisan } \\
\text { dalam media flash } \\
\text { card sangat bagus }\end{array}$ & 40 & 37 & $92,5 \%$ \\
\hline 4 & $\begin{array}{l}\text { Ukuran gambar } \\
\text { dalam media flash } \\
\text { card sangat bagus }\end{array}$ & 30 & 35 & $80 \%$ \\
\hline 5 & $\begin{array}{l}\text { Warna pada media } \\
\text { flash card sangan } \\
\text { bagus }\end{array}$ & 40 & 37 & $92,5 \%$ \\
\hline 6 & $\begin{array}{l}\text { Isi penjelasan } \\
\text { gambar (bagian } \\
\text { depan)sangat jelas. }\end{array}$ & 40 & 37 & $92,5 \%$ \\
\hline 7 & $\begin{array}{l}\text { Media media flash } \\
\text { card memudahkan } \\
\text { saya untuk melihat }\end{array}$ & 40 & 37 & $92,5 \%$ \\
\hline & & & \\
\hline
\end{tabular}




\begin{tabular}{llccc}
\hline 8 & $\begin{array}{l}\text { Media flash card } \\
\text { tidak membosankan }\end{array}$ & 40 & 37 & $92 \%$ \\
\hline Jumlah & $\mathbf{3 2 0}$ & $\mathbf{3 0 5}$ \\
\hline Persentase Klasikal & \multicolumn{3}{c}{$\mathbf{9 6 , 5}$} \\
\hline Kriteria & \multicolumn{2}{c}{ Sangat Setuju } \\
\hline
\end{tabular}

b) Ujicoba Skala Besar

Uji skala besar yang bertujuan untuk melihat keefektifan media flash card dalam pembelajaran Bahasa Indonesia. Pada tahap ini uji skala besar ini akan menilai hasil pemahaman penyampaian materi pada siswa pada pelaksaan pembelajaran dengan menggunakan media flash card analisis respon siswa pada saat pelaksanaan pembelajaran dengan menggunakan media flash card. Berdasarkan data angket respon siswa uji coba skala besar pada pelaksanaan pembelajaran menggunakan media flash card. Hal tersebut menunjukkan Respon siswa pada media pembelajaran flash card memperoleh nilai $94,2 \%$ dengan kriteria "sangat setuju" Hal ini ditunjukkan dengan hasil persentase paling tinggi pada aspek pernyataan 1 dengan pernyataan saya senang melihat gambar pada media flash card meperoleh nilai tinggi yaitu 97,5\% dengan kriteria sangat setuju terhadap media flash card.

\section{SIMPULAN DAN SARAN}

\section{A. Simpulan}

Berdasarkan hasil pengembangan dan penelitian ini makan dapat ditarik kesimpulan bahwa: 1). Rancangan media flash card untuk meningkatkan hasil belajar Bahasa Indonesia, melalui beberapa prosedur yang harus dilakukan. Prosedur tersebut adalah (1) mengkaji dan menganalisi masalah yang aa pada lapangan, (2) pengumpulan data, (3) menentukan desain pengembanagn produk, (4) melakukan implementasi desain (5) Revisi dan validasi ahli media, materi dan Bahasa (6) dari hasil validari kemudian melakukan revisi tahap I, (7) Uji coba kelompok kecil, (8) revisi tahap I, (9) uji coba lapangan (skala bear) dan (10) adalah produk media flash card Sedangkan dalam tahap keefektifan media flash card, 2). Berdasarkan hasil belajar melalui media flash card terdapat peningkatan hasil belajar siswa SDN donggo dori dungga mendapatkan hasil paling skor tinggi $92 \%$ sedangkan pada uji coba skala besar untuk mengetahui keefektifan media flash card terdapat nilai paling skor tertinggi
97,5\%. Dari hasil tes dan uji coba hasil belahar siswa pada skala kecil dan uji coba lapangan (skala besar) disimpulkan bahwa terdapat peningkatan hasil belajar siswa dengan menggunakan media flash card

\section{B. Saran}

Berdasarkan dari pembahasan maka beberapa saran yang diajukan yakni: 1). Penerapan Media pembelajaran pada proses pembelajaran yang seharusnya diteruskan untuk meningkatka pemahaman dan pencapaian pendidikan yang lebih baik. 2). Pengembangan media flash card untuk menunjang proses pembelajaran lebih baik lagi. 3). Media flash card masih memiliki banyak kekurangan, oleh karena itu, peneliti sangat berharap media flash card dapat dikembangkan sesuai dengan kebutuhan dalam dunia pendidikan.

\section{DAFTAR RUJUKAN}

Byram, M., \& Hu, A. (2013). Routledge encyclopedia of language teaching and learning: second edition. New York: Routledge.

Hamalik, Oemar. 2013. Proses Belajar Mengajar. Jakarta: Bumi Aksara.

Indriani, D. 2014. Ragam Alat Bantu Media Pengajaran. Yogyakarta: Diva Press

Mudjiono, Dimyati. 2013. Belajar dan Pembelajaran. Jakarta: Rineka Cipta.

Paolini, A. (2015). Enhancing teaching effectiveness and studentlearning outcomes. The Journal of Effective Teaching, 15(1), 2033.Retrieved from http://search.ebscohost.com/login.aspx?dir ect $=$ true $\& d b=e \quad$ ue $\& A N=10215259$ $0 \&$ site $=$ ehost-live \&scope $=$ site.

Rusman. 2013. Model-model Pembelajaran, Mengembangkan Profesionalisme Guru. Jakarta: Raja Grafindo Persada.

Sudjana, Nana. 2013. Media Pengajaran. Jakarta: PT Raja Grafindo Persada.

Sudjana, Nana. 2013. Media Pengajaran. Jakarta: Raja Grafindo Persada.

Sugiyono, 2015. Metode Penelitian Kualitatif dan R \& D Bandung: Al fabeta 